\title{
Invited review: A perspective on the future of genomic selection in dairy cattle
}

\author{
J. I. Weller, ${ }^{* 1}$ E. Ezra, $†$ and M. Ron* \\ *Institute of Animal Sciences, Agricultural Research Organization, The Volcani Center, Rishon LeZion 7505101, Israel \\ †lsraeli Cattle Breeders Association, Caesarea Industrial Park 3088900, Israel
}

\begin{abstract}
Genomic evaluation has been successfully implemented in the United States, Canada, Great Britain, Ireland, New Zealand, Australia, France, the Netherlands, Germany, and the Scandinavian countries. Adoption of this technology in the major dairy producing countries has led to significant changes in the worldwide dairy industry. Gradual elimination of the progeny test system has led to a reduction in the number of sires with daughter records and fewer genetic ties between years. As genotyping costs decrease, the number of cows genotyped will continue to increase, and these records will become the basic data used to compute genomic evaluations, most likely via application of "single-step" methodologies. Although genomic selection has been successful in increasing rates of genetic gain, we still know very little about the genetic architecture of quantitative variation. Apparently, a very large number of genes affect nearly all economic traits, in accordance with the infinitesimal model for quantitative traits. Less emphasis in selection goals will be placed on milk production traits, and more on health, reproduction, and efficiency traits and on environmentally friendly production with reduced waste and gas emission. Genetic variance for economic traits is maintained by the increase in frequency of rare alleles, new mutations, and changes in selection goals and management. Thus, it is unlikely that a selection plateau will be reached in the near future.
\end{abstract}

Key words: genomic selection, genetic evaluation, quantitative trait locus

\section{INTRODUCTION}

Beginning in the 1950s, progeny test schemes were implemented in dairy cattle breeding programs in most developed countries. The main disadvantage of the progeny test scheme is that although bulls reach sexual maturity at the age of $1 \mathrm{yr}$, they are approximately 5

Received March 17, 2017.

Accepted July 5, 2017.

${ }^{1}$ Corresponding author: joel.weller@mail.huji.ac.il yr old by the time that progeny test records from the first crop of daughters is available. Studies predicting the application of marker-assisted selection in dairy cattle were first published in the 1980s (reviewed by Weller, 2009). Almost all studies assumed that the main gain of marker-assisted selection would be extensive use of young bulls based on both pedigree and marker information. The original studies assumed that a relatively small number of chromosomal segments would be followed by $<100$ markers (e.g., Hayes and Goddard, 2001). Several breeding programs based on this strategy were applied to dairy cattle beginning in the first decade of this century (Bennewitz et al., 2004; Boichard et al., 2006).

With the introduction of high-density SNP chips, including $>50,000(50 \mathrm{~K})$ markers, in 2008, genomic selection became a reality (Van Tassell et al., 2008). This technology was successfully implemented in the United States, Canada, Great Britain, Ireland, New Zealand, Australia, France, the Netherlands, Germany, and the Scandinavian countries (Silva et al., 2014). Adoption of genomic selection breeding programs in the major dairy-producing countries has led to significant changes in the worldwide dairy industry. In this review, we will describe what we have learned from almost 2 generations of application of genomic selection, the changes that have already occurred, those that are likely to take place in the near future, and how these changes will affect the future of the international dairy industry.

\section{HOW HAS 8 YEARS OF GENOMIC SELECTION CHANGED THE DAIRY CATTLE INDUSTRY?}

Since the advent of genomic selection, several changes in the dairy industry are obvious, whereas others are more subtle. Some started soon after launching genomic selection, whereas others are only now coming into play. We have compiled the following list, which may be incomplete.

Extensive data banks containing genomic information on thousands of animals have been established. Programs have been implemented to "trade" genotypes for specific bulls between countries. Agreements between 
countries provided for the exchange of genotypes for Holstein bulls to increase the US, Canada, Italy, UK, Switzerland, and Japan reference populations. Similar agreements between Canada, Denmark, and the United States increased the US Jersey reference population, and through the Intergenomics program, an Interbull initiative, bull genotypes were provided to the Brown Swiss reference population (Wiggans et al., 2017).

Starting in the last 1980s, nearly all advanced breeding programs adopted a version of the individual animal model for routine evaluation of milk production traits and most other economic traits (Westell et al., 1988). Although different methodologies were used in different countries, the differences were generally minor. In the late 1990s, several national evaluation systems adopted "test-day models," in which the record analyzed is the monthly test-day record (e.g., Stanton et al., 1992). With the advent of genomic selection, a plethora of new methodologies was developed: two-step and onestep methodologies, frequentist, and Bayesian. A detailed review of all proposed methodologies is outside the scope of this paper but has been summarized by de Los Campos et al. (2013), Weller (2016b), and Misztal and Legarra (2017). There is currently no consensus on a uniformly "best" method.

The main objective for the establishment of the International Bull Evaluation Service (Interbull; Uppsala, Sweden) was to compute across-country genetic evaluations, taking into account possible genotype $x$ environment interactions. The multiple across-country evaluation (MACE; Schaeffer, 1994) algorithm was developed for this purpose, based on bulls with genetic evaluations in more than a single country (http://www .interbull.org/ib/interbullactivities). The major differences in methodology and the fact that genomic evaluations of young sires still have low reliability relative to progeny test make the question of across-country comparisons of genomic evaluations even more critical. New methodologies have been developed by VanRaden and Sullivan (2010) for this purpose, and were incorporated into the genomic MACE (GMACE) algorithm, which is used by Interbull to compute multi-country genomic evaluations. To date, the United States is the only country with genomic evaluations that are not included in GMACE, which may lower its effectiveness.

Reduction in genotyping costs has led to an exponential increase in the number of animals genotyped per year. In 2010, when 50K SNP chips became widely available, genotyping costs were $>\$ 500$ per individual; now, costs for comparable SNP chips are $\sim \$ 50$. In the North American consortium, 1.6 million Holsteins have been genotyped since 2009 (through mid-2017), of which over 215,000 are males (https://www.uscdcb .com/Genotype/cur_density.html). Costs for lower- density chips are reaching the point at which routine genotyping of all female calves can be economically justified for management decisions at the farm level (Thomasen et al., 2014; Calus et al., 2015).

There has been rapid turnover in the SNP chips used for standard genomic evaluation. By the end of August 2015, 18 chips were submitted to the US Council on Dairy Cattle Breeding (CDCB; Bowie, MD) for use in national genomic evaluations (Wiggans et al., 2016, 2017). As of 2017, the number of chips used for cattle genotyping has increased to 27 (https://www.uscdcb .com/Genotype/cur_freq.html). One factor that drives the creation of new chips is that the pool of bead types used to manufacture a chip becomes exhausted. Even if the goal is to continue the same chip, a new bead pool may yield a slightly different set of SNP that pass performance standards.

Hayes et al. (2012) initiated an international project of whole-genome resequencing of 1,000 bulls with the intent to provide an extended database of variants that could be imputed onto existing cattle SNP genotype data (http://www.1000bullgenomes.com/doco/hayes _pag_1000bullgenomes_2013.pdf; Daetwyler et al., 2014). By September 2016, whole-genome sequences from 1,682 cattle of 55 breeds have been submitted, from which 67.3 million variants (64.8 million SNP, 2.5 million indels) have been identified (Hayes et al., 2016). A total of $14,609,220$ polymorphisms with a minor allele frequency of $>0.01$ were found for Holsteins. After eliminating redundant polymorphisms (i.e., consecutive polymorphisms with $>0.95$ identity) and polymorphisms with low call rates, 3,148,506 polymorphic sites remain (VanRaden et al., 2017). As costs decline, it is likely that complete genome sequencing of AI bulls will become routine.

The Functional Annotation of Animal Genomes (FAANG) consortium (http://www.faang.org/) was established to provide infrastructure to efficiently analyze genome-wide functional data for animal species, starting with chicken, pig, cattle, and sheep, to increase understanding of how variation in gene sequences and functional components determines phenotypic diversity (Andersson et al., 2015). Determination of causative polymorphisms for observed quantitative variation will be discussed in more detail in a separate section.

Until the advent of genomic evaluation, gains in efficiency of breeding programs due to increases in scale were minimal above population sizes of $\sim 100,000$ milkrecorded cows. Thus, many countries were able to run national breeding programs, and the largest countries were able to conduct breeding programs for more than a single breed. With genomic evaluation, the consensus is that the main factor limiting the accuracy of genomic evaluations is the number of bulls with genotypes and 
daughter records (e.g., VanRaden et al., 2009). Thus, even the largest countries are pooling resources to conduct multi-national genomic selection programs. Two major consortiums have been established: the North American consortium, which includes organizations from the United States, Canada, United Kingdom, Italy, Switzerland, and Japan; and Eurogenomics, which includes members from Spain, the Netherlands, France, Poland, Denmark, Sweden, and Finland (http://www .eurogenomics.com/). Membership in the consortiums is dependent on submission of a quota of bulls with genotypes and genetic evaluations based on daughter records. Smaller countries that are not able to meet this requirement, such as Israel and Ireland, have initiated joint genomic evaluations with larger countries (e.g., Weller et al., 2015; Lund et al., 2016).

A corollary of these developments is that genomic selection programs for the minor breeds; that is, all breeds other than Holsteins, are becoming more difficult to justify economically (Calus, 2016). The huge number of genotyped animals required to obtain even moderately reliable genomic evaluations is especially acute with respect to novel traits such as feed efficiency.

There have been major reductions in generation intervals, especially along the sire-of-bull and dam-of cow paths. In US Holsteins, generation intervals along these paths were reduced from 7 to 2.4 and $5 \mathrm{yr}$, respectively (García-Ruiz et al., 2016). The change in the sire-of-cow interval was smaller, from 3.8 to $3.6 \mathrm{yr}$, even though this was originally assumed the main pathway to increase genetic gain via genomic selection. It is likely that this interval will decrease further as genomic evaluations receive more widespread acceptance.

The number of new AI bulls produced per year has decreased. The number of Holstein bulls with daughter records by birth year is shown in Figure 1A for the sum of 6 countries (United States, Canada, Germany, France, Netherlands, and Israel); in Figure 1B for the United States; in Figure 1C for Germany; and in Figure $1 \mathrm{D}$ for Israel. Considering all 6 countries, the number of bulls with daughter records has decreased from $\sim 4,500$ in 1995 to $\sim 2,500$ in 2010, the last birth year for which nearly complete data are available. Although the number of US bulls with daughters decreased from $\sim 1,500$ to $\sim 1,100$, for Germany, France, and the Netherlands, the number of bulls with daughters was reduced by more than half. The decrease was most dramatic in Germany, which progeny tested $>1,000$ bulls born in 1996, but only 308 in 2011. The number of bulls progeny tested in Israel has remained roughly constant but genomic selection began only in 2015. Although the progeny test of young bulls with 50 to 100 daughters has not been eliminated, numbers of bulls have decreased, and the mean number of daughters per young bull has increased. This reduction has significant implications for niche markets and international sales, as fewer outlier bulls with special adaptations will be available.

Before genomic selection, the paternity misidentification rate in advanced breeding populations was estimated to be in the range of 5 to $12 \%$ (Ron et al., 1996). Highly accurate paternity validation or identification based on comparison of progeny and parent genotypes is a virtually no-cost byproduct of genotyping that is required for genomic evaluation (Weller et al., 2010), which should also increase rates of genetic improvement.

In the progeny test scheme, a second crop of daughters was produced from elite bulls approximately $5 \mathrm{yr}$ after the first crop. With genomic selection, most bulls are used for general service for $1 \mathrm{yr}$ or less and then retired; only a very small sample of elite bulls produce a second crop of daughters. The lack of ties between bulls of different ages will make it more difficult to obtain accurate genetic evaluations across generations (Liu et al., 2016).

Daughters are produced only from bull calves with high genomic evaluations. These bulls are a selected sample with respect to the Mendelian sampling component of the genetic variance of their parents. The genetic value of an individual can be decomposed into the contribution from its sire, its dam, and a Mendelian sampling component, which should account for half of the genetic variance in the population. However, if bull calves are selected based on genotype, then only individuals with high Mendelian sampling effects will be selected, which will bias evaluations based on the standard relationship matrix (Patry and Ducrocq, 2011). Selection of bulls out of an already selected population can also result in bias in the calculated genetic gain (Calus et al., 2015).

Implementation of genomic evaluation has also lead to inclusion of more traits in the selection indices, and reduction of the emphasis on protein and fat production and conformation traits (Egger-Danner et al., 2015; Chesnais et al., 2016; Weller, 2016a). More emphasis is expected on health and reproduction traits, direct selection on production efficiency, and selection for environmentally friendly production, including reduced waste production and gas emission (Schöpke and Swalve, 2016; de Haas et al., 2017).

Several studies predicted that new reproductive technologies, such as embryo transplant and multiple ovulation, would have a major effect on genomic selection (e.g., Bouquet and Juga, 2013). With the exception of sexed semen, new reproduction technologies have had, to date, only minimal impact on commercial breeding programs (García-Ruiz et al., 2016), even though Thomasen et al. (2016) proposed that incorporation of 
reproductive technologies into genomic selection programs is economically justified. However, AI organizations have begun using in vitro fertilization (IVF) heavily and selecting embryos for implantation based on genotype, which should reduce the generation interval along the sire-to-bull pathway by up to 7 mo (Wiggans et al., 2017).

\section{WHAT HAVE WE LEARNED FROM 8 YEARS OF GENOMIC SELECTION?}

The conclusions that can be derived from nearly 2 generations of genomic selection in the US Holstein population, reviewed chiefly by García-Ruiz et al. (2016), are as follows.

Annual rates of genetic gain increased from $\sim 50$ to $100 \%$ for yield traits and from 3 -fold to 4 -fold for lowly heritable traits, including female fertility, herd life, and
SCC. It should be noted though that these calculations are based on genomic evaluations and generally have not been validated by bulls with evaluations based on daughter records. The major engine of gain was the use of much younger bulls as bull sires. Annual genetic gain is computed as the sum of genetic gain per generation over the 4 paths of inheritance, divided by the sum of the 4 generation intervals. The sire-to-bull generation interval reduced from $\sim 7 \mathrm{yr}$ before 2008 to $\sim 2.5 \mathrm{yr}$ in 2015. Although several studies have found that genomic evaluations of young bulls are somewhat biased relative to their later evaluations based on daughter records (e.g., Liu et al., 2016), the estimates of genetic trends are not significantly biased.

Accuracy for selection of bull dams has increased and the mean generation interval has declined from 4 to 2.5 yr. Evaluations of elite cows have traditionally been biased due to preferential treatment in the US popu-
A
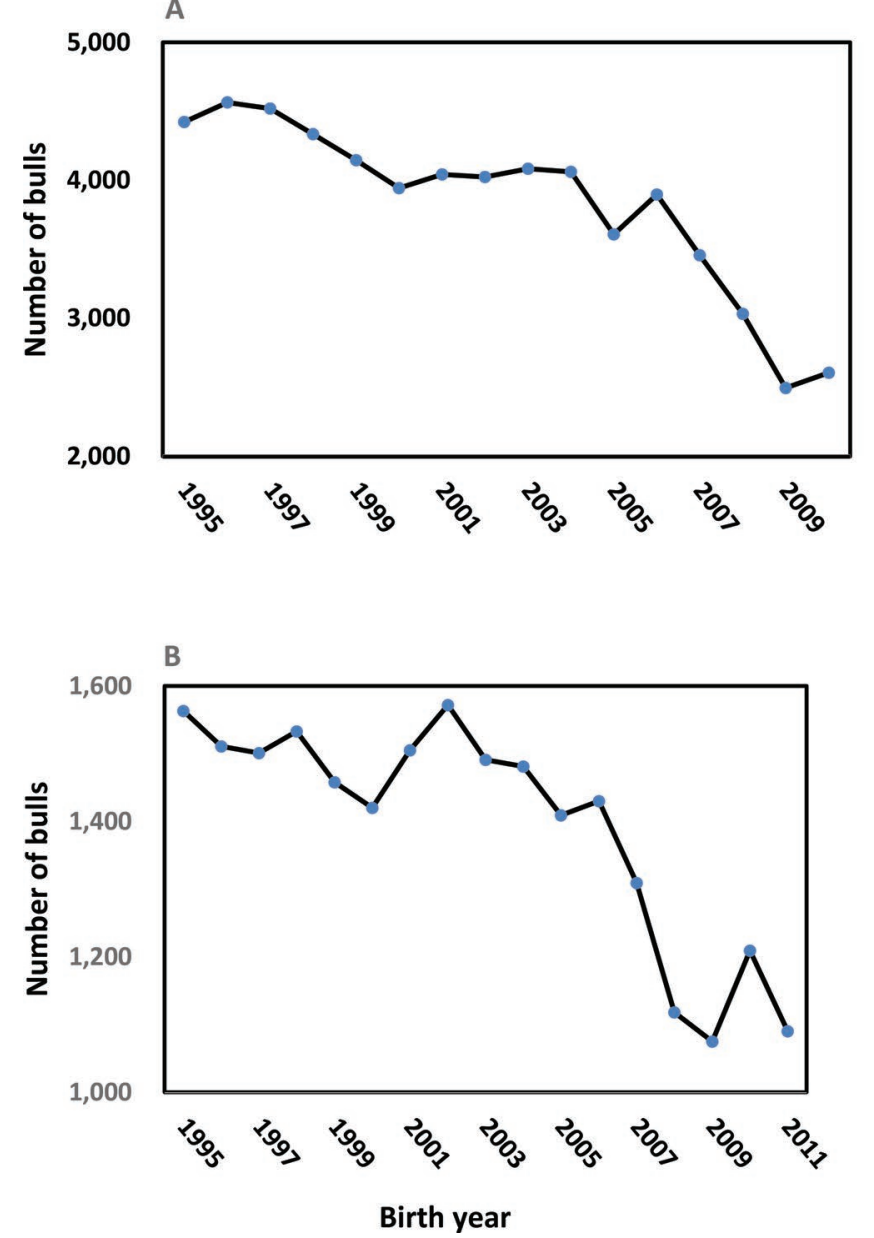

C
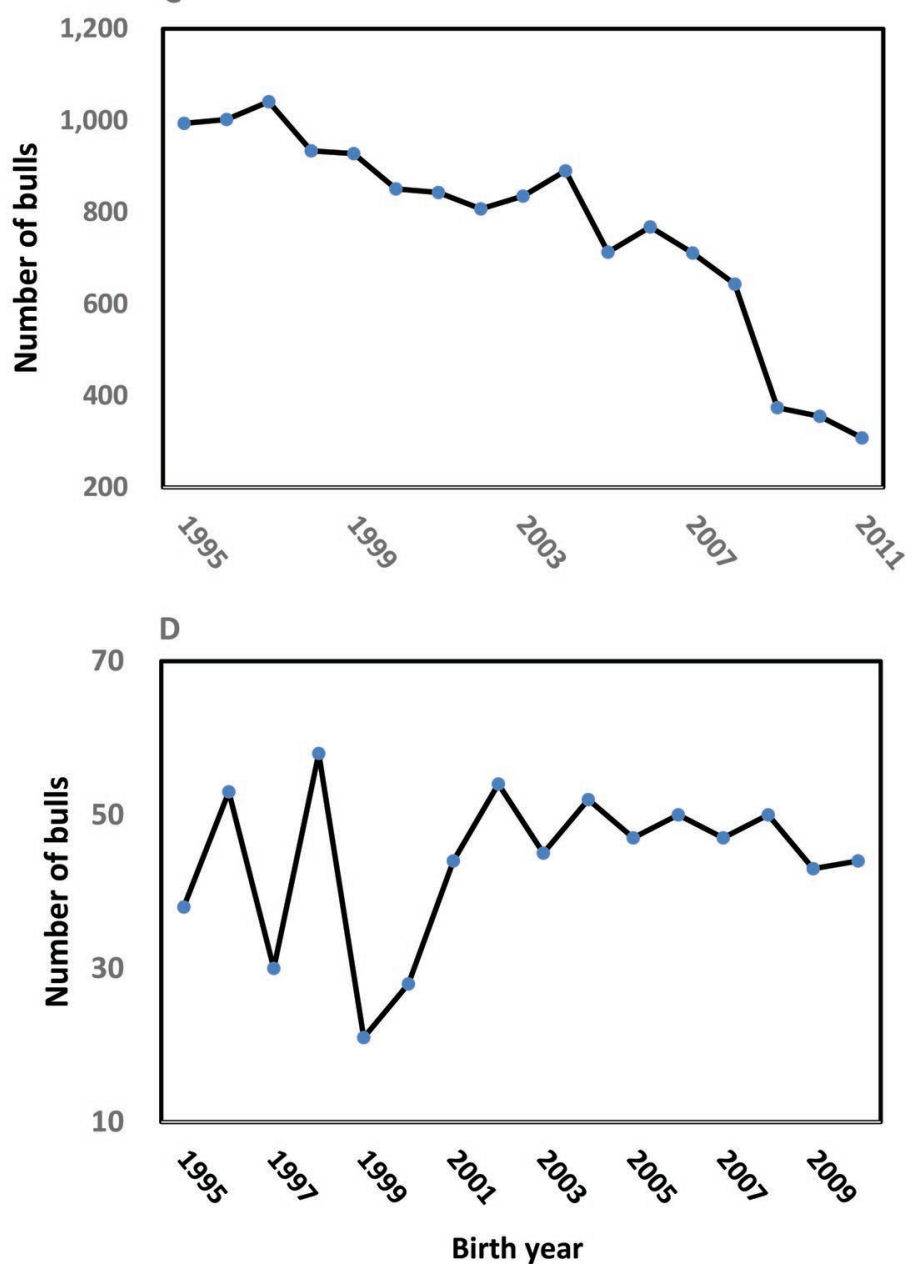

Figure 1. Number of Holstein bulls with daughter records by birth year: (A) sum of 6 countries (United States, Canada, Germany, France, the Netherlands, and Israel); (B) United States; (C) Germany; (D) Israel. These values were derived from the International Bull Evaluation Service (Interbull, Uppsala, Sweden) summaries. Color version available online. 
lation. With genomic evaluation, the effect of biased performance records has been reduced, although bias may increase again now that the common practice is to hold back "early release" semen of the top bulls for only IVF labs and matings to elite females (Wiggans et al., 2017).

Pryce and Daetwyler (2012) predicted that the rate of inbreeding would be lower per generation in genomic breeding programs than in progeny testing, because Mendelian sampling terms can be estimated more accurately, but that shorter generation intervals would lead to higher rates of inbreeding per year. In practice, genomic selection in the US population had only a minor effect on rates of change of inbreeding or expected future inbreeding derived from pedigrees. There was an increase from 0.11 to $0.21 \%$ per year in 2012 , but no evidence of a change in the rate of expected future inbreeding since 1997. For genotyped bulls with performance records on daughters, the change in genomic inbreeding was stable, at $0.07 \%$ increase per year since 1998. In conclusion, the genetic progress achieved by application of genomic selection conforms to Hill's statement: "Breeders are simply giving evolution a push using the technology available" (Hill, 2016).

\section{WHAT ABOUT THE GENES?}

Before genomic selection, most studies that attempted to simulate the underlying genes for quantitative traits assumed a distribution that postulated a few large QTL and many small ones (Weller, 2009). For example, Hayes and Goddard (2001) assumed a gamma distribution. However, once actual results became available, it became clear that these theoretical models were generally off the mark. As noted by Goddard et al. (2016), "in almost every trait studied there are thousands of polymorphisms that explain genetic variation." That is, the infinitesimal model for quantitative traits of Fisher (1918) is basically correct.

The first high-density scan in dairy cattle using 38,416 SNP markers for 5,285 Holstein bulls confirmed ABCG2 (Cohen-Zinder et al., 2005) and DGAT1 (Grisart et al., 2002; Winter et al., 2002), but revealed few other large effects (Cole et al., 2009). Cole et al. (2009) concluded that genetic effects for many dairy traits and for total economic merit are more or less evenly distributed across all chromosomes. Cattle SNP effects are now estimated from $>400,000$ cows with genotypes and phenotypes plus 35,000 proven bulls, and are updated every 4 mo: https://www.uscdcb.com/Report_Data/ Marker_Effects/marker_effects.cfm. Maher (2008) summarized results for genome scans in humans, especially with respect to height. Although this trait has a heritability of 0.90 , and the number of individuals genotyped and scored for this trait was $>30,000$ in a single study, only $5 \%$ of the genetic variance could be explained by identified QTL. Furthermore, the largest genes detected only accounted for a few millimeters. Suggested explanations include the existence of gene $x$ gene or gene $\times$ environment interactions, the common disease-rare variant hypothesis, and the possibility that inherited epigenetic factors cause resemblance between relatives (Yang et al., 2010). None of these are very satisfactory explanations. It now seems that the simplest explanation is the most correct. That is, genetic variance in human height, as is the case for almost all quantitative traits, is controlled by a very large number of loci, each with a very small effect (Yang et al., 2010).

The current release of the Cattle QTL database contains 95,332 QTL or associations from 743 publications for 545 different traits (Hu et al., 2016). Because of differing trait definitions, possible genetic differences between populations, and the relatively large confidence intervals for QTL location, it is unclear how many of these associations can be considered confirmed by independent studies. A large fraction of studies have not corrected for multiple comparisons. That is, if many marker-by-trait combinations are tested, then several will display "nominal" significance at $P<0.05$ by chance (Weller et al., 1998). Khatkar et al. (2004) performed a meta-analysis, using those studies published up to 2003 that included the 5 milk production traits and SCS, and were able to determine that only a few effects were consistent across several studies.

Wiggans et al. (2016) list 30 single-gene tests that were selected for use in routine genomic evaluations, because they were identified as causative variants or closely linked to ones. Of these, 18 had minor allele frequencies $<0.01$ in Holsteins. Four of these are termed "fertility haplotypes." These haplotypes were detected based on 2 criteria: (1) reduction of female fertility, relative to the alternative haplotypes in the same chromosomal locations; and (2) lack of homozygotes. These haplotypes are presumed to contain recessive lethal alleles that result in early stage abortions. Thus, on a practical level, conception is not recorded, and "fertility" is reduced. Putative causative polymorphisms have been determined for 3 of these haplotypes (Sonstegard et al., 2013; McClure et al., 2014; Adams et al., 2016).

To date, the specific polymorphisms responsible for variance in quantitative traits in dairy cattle have been identified and validated only for DGAT1 and $A B C G 2$ (Ron and Weller, 2007). From the time that a segregating QTL was first detected on chromosome 14 by application of the daughter design in the Israeli Holstein population (Ron et al., 1998), it took 4 yr to identify the causative polymorphism in DGAT1 (Grisart et al., 2002; Winter et al., 2002). It took 10 yr from the 
first detection of a segregating QTL on BTA6 in the US Holstein population (Georges et al., 1995) until the causative polymorphism in ABCG2 was identified (Cohen-Zinder et al., 2005). No additional causative polymorphisms have been verified in the last decade based on the criteria presented by Ron and Weller (2007), in spite of advancements in methods for gene identification and validation, such as genotyping-bysequencing, whole-genome sequencing, genome editing, and functional assays (Georges, 2007; De Donato et al., 2013; Tan et al., 2013).

\section{THE EFFECT OF SELECTION ON GENETIC VARIANCE}

Bayesian methods that differentially weigh markers or even give weights of zero to a fraction of markers have not been found to be consistently more accurate than linear genomic methods. This is also the case for methods based on analysis of a subset of markers preselected based on the magnitude of their effects in a "training population" (Weller et al., 2014b). From this, we can reach 2 important conclusions:

(1) As noted previously, the number of genes with effects on a quantitative trait is quite large.

(2) The genetic variance contributed by specific polymorphisms changes over time due to selection.

The second point will be illustrated using the example of a QTL with 2 alleles with additive effects. The genetic variance contributed by this gene is $2 q(1$ $-q) \alpha^{2}$, where $q=$ the frequency of one allele and $\alpha=$ the allele substitution effect. The expected change in gene frequency per generation, $\Delta q$, resulting from mass selection is computed as follows (Falconer, 1964):

$$
\Delta q=i q(1-q) \frac{\alpha}{\sigma_{p}}
$$

where $i=$ selection intensity, $q=$ allele frequency before selection, $\alpha=$ the allele substitution effect, and $\sigma_{p}=$ phenotypic standard deviation. Because selection is generally for an index, $i$ must be computed relative to each trait; that is, the selection intensity times the genetic correlation between the index and the specific trait. Expected changes in allelic frequencies and variance due to selection, as a function of the frequency of the favorable allele and allele substitution effect in units of the phenotypic standard deviation, are given in Figure 2 for 3 values of $\alpha$ over the range of 0.1 to 0.9 for $q$. A biallelic QTL with complete codominance and a se- lection intensity of unity is assumed. Although it is generally assumed that selection reduces genetic variance, it can be seen that if the frequency of the favorable allele is $<0.5$, genetic variance is increased by selection. For a gene with $\alpha=0.4$ phenotypic standard deviations and an initial frequency of 0.5 , frequency of $q$ is increased by 0.1 after a single generation of selection. If $q=0.1$ and $\alpha=0.4$, the variance due to this gene in the following generation will increase by $1 \%$ of the phenotypic variance.

In practice, genomic selection is based on populationwide linkage disequilibrium between genetic markers and causative genes. Effects associated with specific markers will decay in future generations as a function of the linkage distance between the markers and the causative genes.
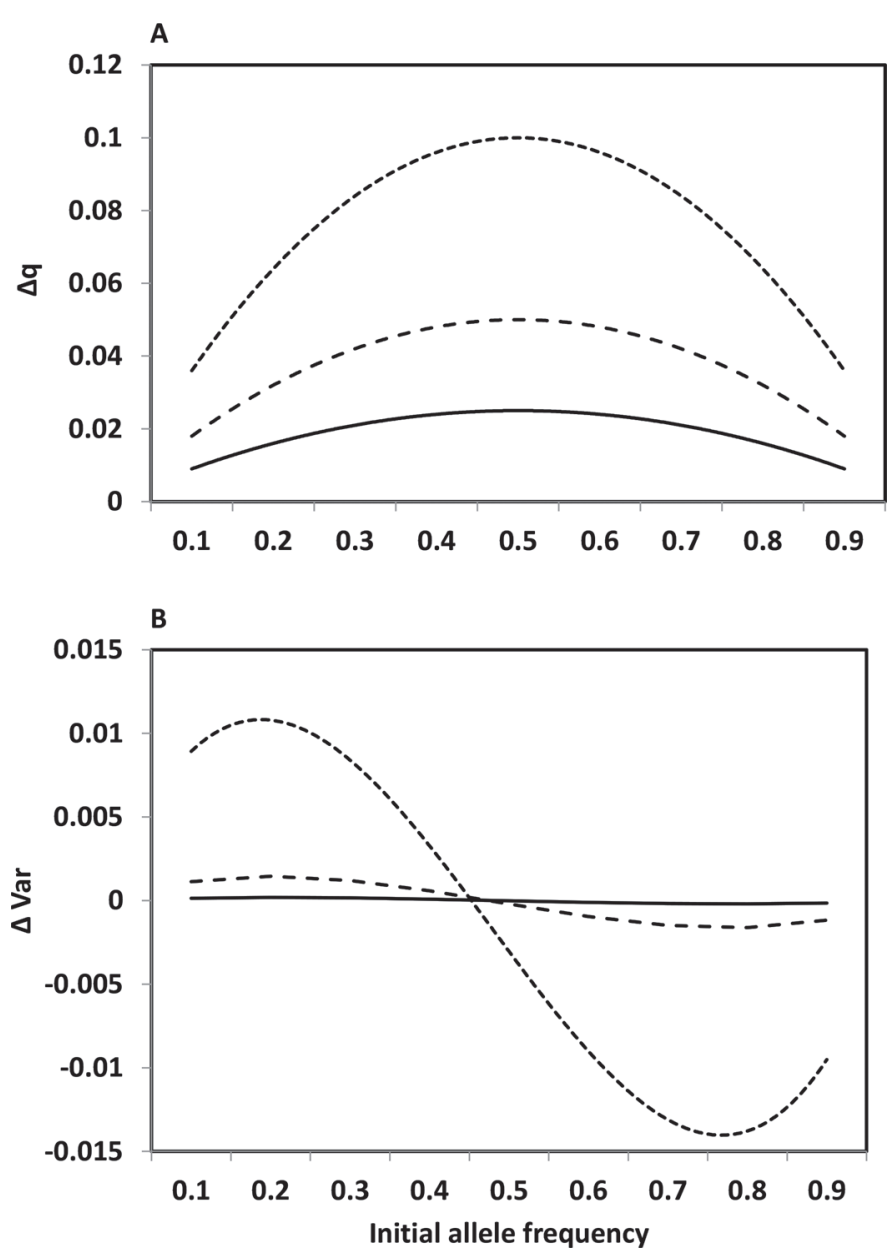

Figure 2. Expected changes in (A) allelic frequencies $(\Delta q)$, and (B) variance $(\Delta$ Var $)$ due to selection, as a function of the frequency of the favorable allele and allele substitution effect in units of the phenotypic standard deviation. A biallelic QTL with complete codominance and a selection intensity of unity is assumed. Solid, dashed, and dotted lines indicate allele substitution effect $=0.1,0.2$, and 0.4 , respectively. 
In addition to the sources of bias in genomic evaluations noted previously, these factors partially explain the bias observed in genomic evaluations of young bulls compared with their later evaluations based on daughter records. Changes in the genetic variance due to specific markers can also explain why selection of a subset of markers for genomic evaluation has not been successful. Weller et al. (2014a) demonstrated that selection of subsets of markers based on their effects in a "training sample" of bulls was very effective to predict breeding values for other animals of the same age, but was virtually no better than random selection of markers for a 4 -yr-younger cohort of animals. It may also be necessary to tailor training population samples to the target populations; for example, the selection of different training populations for different countries.

\section{IS A SELECTION PLATEAU ON THE HORIZON?}

Since the 1970s, mean annual milk production in Israel has almost doubled from 7,000 to $13,000 \mathrm{~kg}$; similar changes have occurred in other countries (Rauw et al., 1998). Genetic theory suggests that at some point, genetic progress might plateau either through exhaustion of genetic variability or through development of antagonistic genetic relationships between the selection objective and components of fitness. In addition, the principle of diminishing economic returns may result in a virtual economic gain plateau. In long-term selection experiments, the selection response usually ends after 20 to 30 generations (Kennedy, 1984), although, in some cases, a significant response has continued for over 100 generations (Hill, 2008). Despite these considerations, heritability of lactation milk yield in dairy cattle has actually risen from $\sim 25 \%$ in the 1950 s to $\sim 35 \%$ currently, likely partly due to improved management (Hill, 2016). Apparently, little variation has been lost and current rates of genetic gain are indeed sustainable in the future. As noted in the previous section, selection can also increase genetic variance if the frequency of the favorable allele is low. The cryptic "rise and fall" of genes affecting economic traits is one of the mechanisms through which genetic variation is maintained.

The 2 known polymorphisms in $A B C G 2$ and DGAT1 clearly have the greatest effects relative to the trait genetic standard deviation of all detected QTL in dairy cattle (Weller et al., 2014a). Both mutations occurred after the separation of the indicus and taurus lineages over 200,000 yr ago but before the development of modern cattle breeds (Loftus et al., 1999; Kaupe et al., 2004; Ron et al., 2006). Because these mutations are relatively ancient, it is therefore reasonable to ask why these polymorphisms have been maintained in the population. The allele of $A B C G 2$ that increases milk production decreases protein concentration. Thus, when breeding was chiefly for milk quantity, this was the favorable allele, and its frequency increased in the Israeli Holstein population. When the index changed so that protein was the major objective and the economic value for milk quantity was negative, selection was applied in the opposite direction, and the frequency of the allele that decreased milk quantity increased (Cohen-Zinder et al., 2005). With respect to DGAT1, the allele that increases fat production and concentration decreases protein quantity. Thus, for most selection indices used in dairy cattle breeding programs (Miglior et al., 2005), the net effect of this polymorphism is close to zero, and virtually no selection potential is applied to it (Weller et al., 2003). However, a major change in the index could lead to a situation in which 1 of the 2 alleles would have an economic advantage. This would result in an "increase" in the genetic variance for the index, if the less frequent allele were economically favorable. Based on analysis of 11 segregating QTL in Holsteins, Kemper et al. (2015) concluded that the age of the QTL mutations appears to vary from perhaps 2,000 to 50,000 generations. The older QTL tend to have high derived allele frequencies and often segregate across more than one breed.

The related physiological consequences of the doubling of milk production per cow over the last $50 \mathrm{yr}$, such as negative energy balance, attenuation of heat stress, and so on, constitute challenges for which new polymorphic genes are exposed and their favorable alleles are recruited through selection for the best performing cattle. The gradual changes in allele frequencies of a large pool of variants with very small phenotypic effects have been termed "polygenic adaptation" (Druet et al., 2014). Thus, relatively ancient polymorphisms in multiple genes with low minor allele frequencies may be "waiting" for the appropriate environment.

Finally, we should consider the effect of new mutations in generation of genetic variance for quantitative traits. Although the frequency of QTL mutation has not been addressed for farm animals, studies in various plant and model animal species have shown that the spontaneous occurrence of mutation for genes affecting quantitative traits is probably greater than mutations of the major genes (reviewed by Weber, 1985). The main methodology used to detect new mutations for quantitative traits is to first generate homozygous inbred lines and then determine that heritable changes in expression of quantitative traits have occurred in future generations. Spontaneous mutation rates at viability loci in Drosophila were estimated to be 0.14 per chromosome per generation. Deol et al. (1957) found 
218 variants affecting 27 skeletal traits in mice over 72 generations, which reduced to a rate of 0.01 mutations/ trait per generation.

\section{FUTURE CHALLENGES}

\section{Inclusion of New Traits}

Probably the most important challenge will be incorporation of new traits into the selection index, including udder health, hoof health, other health traits, feed efficiency, and methane emissions (Egger-Danner et al., 2015; Chesnais et al., 2016; Schöpke and Swalve, 2016; de Haas et al., 2017). Although most researchers agree as to the economic importance of these traits, they have not generally been included in breeding programs because of difficulty of measurement or low heritability (for nearly all health traits). Thus, numbers of daughter records or genotyped cows must be huge to obtain reliabilities $>0.50$, which is the accepted value for publication of evaluations. However, with reliabilities $<0.50$, meaningful genetic progress can still be made, depending on other factors, including the genetic correlation with the overall index and the economic value of the new trait (Calus et al., 2013).

Because feed generally accounts for as much as half of all direct costs in milk production, there has been major interest in selection for feed efficiency. However, individual feed consumption is expensive and difficult to measure. It can generally be accomplished only by individual feeding, which is not the norm in most commercial enterprises. The Global Dry Matter Initiative, which includes 10 research herds from 9 countries (Australia, Canada, Denmark, Germany, Ireland, the Netherlands, New Zealand, United Kingdom, and United States) was established to combine feed intake records from different sources to create a large cow reference population for genomic selection (de Haas et al., 2015).

In addition to selection for health, fertility, and feed efficiency, breeding for environmentally friendly animals that produce less waste and greenhouse gases may also be a major goal of selection. Because total waste production is largely a function of the number of animals raised, increasing milk production per animal should decrease total waste production. Thus, despite diminishing economic returns for each unit increase, production per animal will continue to be an important selection objective.

Globally, livestock contributes 18\% (7.1 billion tonnes of $\mathrm{CO}_{2}$ equivalents) of global greenhouse gas emissions (http://www.fao.org/agriculture/lead/themes0/ climate/en/). All direct methods to measure methane emission are prohibitively expensive for data collection on large populations. Roehe et al. (2016) found that sire progeny groups differed significantly in their methane emission measured in respiration chambers. Yin et al. (2015) developed a strategy that combines deterministic equations and stochastic simulations to predict daily methane emission based on routinely recorded on-farm data of feed intake and production. The heritability of predicted lactation methane emission is 0.44 . Genetic correlations with both milk production and days open are $>0.8$. Thus, selection to reduce methane emission will improve fertility as measured by days open, but impede selection for milk production. This, of course, does not preclude inclusion of this trait in a selection index but does mean that genetic gain for the other traits will be somewhat reduced.

Ranking of the sire progeny groups based on methane emission or relative archaeal abundance is consistent overall and within diet, suggesting that archaeal abundance in ruminal digesta is under host genetic control, and can be used to genetically select animals without measuring methane emission directly, although other alternatives have been suggested (de Haas et al., 2017). The use of this criterion will allow genetic analysis on a large number of hosts, which was previously a significant barrier to determination of host genetic effects on methane emission. These results provide a proof of principle that there is an additive genetic influence of the host on its microbiome, and that selection for the desired host can be based on the abundance of a suite of genes in the ruminal metagenome associated with the trait. Population genetic studies in cattle lend supporting evidence for a genetic influence of the host on methane production (reviewed by Pickering et al., 2015; Manzanilla-Pech et al., 2016; de Haas et al., 2017).

Of course, this assumes that political considerations driving environmentally friendly production will remain roughly constant in the foreseeable future, at least in the major dairy production countries - or that the industry will consistently aim to improve sustainability. We have no choice but to leave this question unanswered.

\section{Identification of Causative Genes}

Darvasi (2005) wrote, "I have no doubt that in the future dissecting a quantitative phenotype into its underlying genes will become a routine task achieved in a timeframe of one year - possibly in 80 days." Although this statement refers to mice, it appears that the challenge of understanding complex trait genetics in both farm animals and human is far more complex. In spite of the fact that only 2 causative polymorphisms for milk production traits in cattle have been verified by both statistical and biological methods, additional genes may be found, especially for new traits that are to be included in the selection indices of the future. 
Although the contribution of such potential findings to commercial breeding will likely be minimal, this knowledge will broaden our understanding of the genetic architecture of quantitative variation. The polymorphisms in both genes were nonconservative missense mutations, capable of encoding a change in amino acid in the produced protein (Grisart et al., 2002; Winter et al., 2002; Cohen-Zinder et al., 2005). Blott et al. (2003) identified a missense mutation in the growth hormone receptor gene that displayed almost complete concordance and may be a causative polymorphism. Recently, Littlejohn et al. (2016) identified an intronic SNP in the MGST1 gene, which chiefly affects fat concentration, similar to DGAT1, and that may be the causative mutation, although mode of action is unknown. Of the 2 identified causative polymorphisms in other farm animals, GDF8 in sheep is a transition in the 3 '-untranslated region (UTR), and IGF2 in swine is an intronic SNP (reviewed by Ron and Weller, 2007). The IGF2 mode of action also involves male imprinting.

Based on the a posteriori granddaughter design, which uses imputed whole-genome sequence, and other methodologies, additional segregating QTL have been detected for almost all economic traits (Weller et al., 2014a; Wiggans and Weller, 2015) but causative polymorphisms have not yet been verified.

\section{Proposed Changes in Genomic Evaluation Methodology}

Adding more ancestors to the pedigree should increase estimated reliability (Cooper et al., 2015), provided that the analysis model is correct. However, even for traits that have been recorded for several generations, it is doubtful that these historical records should be included in routine genomic evaluations for several reasons. As demonstrated by Glick et al. (2012) and Weller et al. (2014b), the frequencies of the important segregating genes change over time. In Israeli Holsteins, the frequency of the DGAT1 allele that increases fat concentration and quantity increased from 0.02 to 0.13 over $9 \mathrm{yr}$, and the allele of $A B C G 2$ that increases protein concentration increased from 0.62 to 0.78 over 12 yr (Weller et al., 2003; Cohen-Zinder et al., 2005). Thus, for both genes, the allele frequency change was $>0.05$ per generation. Across-breed comparison showed that frequency of the $A B C G 2$ allele that increases protein concentration varied between 0.8 and 1.0 in 35 cattle breeds (Ron et al., 2006). If all bulls with genomic evaluations are included, then more weight will be given to older bulls, considering that the number of bulls with daughter records is decreasing. As shown by Lourenco et al. (2014), accuracy of genomic evaluations did not increase by inclusion of more than 3 generations of ancestors.

The main opportunity that has yet to be exploited with respect to genomic evaluation is the huge number of genotyped cows. As noted previously, more than 1 million Holstein cows have already been genotyped (Taylor et al., 2016), and Decker (2015) predicted 3 million genotyped Holsteins by 2021. Various studies have proposed deriving genomic evaluations for small populations based on genotypes of cows (e.g., Jenko et al., 2017; Uemoto et al., 2017). Pryce et al. (2012) estimated that reliabilities of genomic evaluations could be increased by up to $7 \%$ with the incorporation of 10,000 cow genotypes in addition to 3,000 bull genotypes. For a trait with heritability of 0.30 and cows with single records, $<10$ genotyped cows yield information equivalent to a single progeny-tested bull with a reliability of 0.8 (Boichard et al., 2015).

Direct incorporation of cow evaluations or yield deviations into genomic evaluation algorithms based on analysis of sire daughter yield deviations have been shown to be problematic due to problems of scale (Wiggans et al., 2012). With genotyping costs of $<\$ 50$ per animal and accurate imputation techniques, we predict that future genomic evaluation algorithms will be based on single-step methodologies incorporating hundreds of thousands of cows with genotypes and trait records (e.g., Koivula et al., 2016; Mäntysaari and Strandén, 2016). Problems with convergence of solutions in single-step methodologies were noted by Misztal and Legarra (2017). However, in all actual applications of single-step methodology to date, only a very small fraction of the animals included in the analysis actually have genotypes (Aguilar et al., 2010). It is likely that convergence problems will decrease if a larger fraction of the population is genotyped. Because cows generally produce from 3 to 5 lactation records, the current problem of shortage of genetic ties between bulls from different cohorts will also be solved.

\section{CONCLUSIONS}

Genomic selection has led to enhanced rates of genetic improvement, shortening of generation intervals, reduction in the number of bulls with daughter records, and fewer genetic ties across years. We predict that greater use will be made of cow genomic evaluations and the adoption of single-step methodologies for genomic evaluation. More emphasis will be placed on health, reproduction, efficiency of production, and environmentally friendly production. Genetic variance for economic traits is maintained by increase in frequency of rare alleles, new mutations, and changes in 
selection goals and management. Thus, it is unlikely that a selection plateau will be reached in the near future. The pioneering application of genomic selection in cattle will affect other livestock.

\section{ACKNOWLEDGMENTS}

This research was supported by grant number 588042-5-063F from the U.S.-Israel Binational Agricultural Research and Development (BARD; Rishon LeZion, Israel) Fund. We thank the editor and reviewers for many useful comments.

\section{REFERENCES}

Adams, H. A., T. S. Sonstegard, P. M. VanRaden, D. J. Null, C. P Van Tassell, D. M. Larkin, and H. A. Lewin. 2016. Identification of a nonsense mutation in APAF1 that is likely causal for a decrease in reproductive efficiency in Holstein dairy cattle. J. Dairy Sci. 99:6693-6701.

Aguilar, I., I. Misztal, D. L. Johnson, A. Legarra, S. Tsuruta, and T. J Lawlor. 2010. Hot topic: A unified approach to utilize phenotypic, full pedigree, and genomic information for genetic evaluation of Holstein final score. J. Dairy Sci. 93:743-752.

Andersson, L., A. L. Archibald, C. D. Bottema, R. Brauning, S. C Burgess, D. W. Burt, E. Casas, H. H. Cheng, L. Clarke, C. Couldrey, B. P. Dalrymple, C. G. Elsik, S. Foissac, E. Giuffra, M. A. Groenen, B. J. Hayes, L.-S. S. Huang, H. Khatib, J. W. Kijas, H. Kim, J. K. Lunney, F. M. McCarthy, J. C. McEwan, S. Moore, B. Nanduri, C. Notredame, Y. Palti, G. S. Plastow, J. M. Reecy, G. A. Rohrer, E. Sarropoulou, C. J. Schmidt, J. Silverstein, R. L. Tellam, M. Tixier-Boichard, G. Tosser-Klopp, C. K. Tuggle, J. Vilkki, S. N. White, S. Zhao, and H. Zhou. 2015. Coordinated international action to accelerate genome-to-phenome with FAANG, the Functional Annotation of Animal Genomes project. Genome Biol. 16:57.

Bennewitz, J., N. Reinsch, F. Reinhardt, Z. Liu, and E. Kalm. 2004. Top down preselection using marker assisted estimates of breeding values in dairy cattle. J. Anim. Breed. Genet. 121:307-318.

Blott, S., J.-J. Kim, S. Moisio, A. Schmidt-Küntzel, A. Cornet, P. Berzi, N. Cambisano, C. Ford, B. Grisart, D. Johnson, L. Karim, P. Simon, R. Snell, R. Spelman, J. Wong, J. Vilkki, M. Georges, F. Farnir, and W. Coppieters. 2003. Molecular dissection of a quantitative trait locus: A phenylalanine-to-tyrosine substitution in the transmembrane domain of the bovine growth hormone receptor is associated with a major effect on milk yield and composition. Genetics 163:253-266.

Boichard, D., V. Ducrocq, and S. Fritz. 2015. Sustainable dairy cattle selection in the genomic era. Invited review. J. Anim. Breed. Genet. $132: 135-143$.

Boichard, D., S. Fritz, M. N. Rossignol, F. Guillaume, J. J. Colleau, and T. Druet. 2006. Implementation of marker-assisted selection: Practical lessons from dairy cattle. Proc. 8th World Cong. Genet. Appl. Livest. Prod., Belo Horizonte, MG, Brazil. WCGALP, Belo Horizonte, MG, Brazil.

Bouquet, A., and J. Juga. 2013. Integrating genomic selection into dairy cattle breeding programmes: A review. Animal 7:705-713.

Calus, M. P., P. Bijma, and R. F. Veerkamp. 2015. Evaluation of genomic selection for replacement strategies using selection index theory. J. Dairy Sci. 98:6499-6509.

Calus, M. P. L. 2016. Editorial: Genomic selection with numerically small reference populations. Animal 10:1016-1017.

Calus, M. P. L., Y. de Haas, M. Pszczola, and R. F. Veerkamp. 2013. Predicted accuracy of and response to genomic selection for new traits in dairy cattle. Animal 7:183-191.
Chesnais, J. P., T. A. Cooper, G. R. Wiggans, M. Sargolzaei, J. E. Pryce, and F. Miglior. 2016. Using genomics to enhance selection of novel traits in North American dairy cattle. J. Dairy Sci. 99:2413-2427.

Cohen-Zinder, M., E. Seroussi, D. M. Larkin, J. J. Loor, A. Evertsvan der Wind, J. H. Lee, J. K. Drackley, M. R. Band, A. G. Hernandez, M. Shani, H. A. Lewin, J. I. Weller, and M. Ron. 2005. Identification of a missense mutation in the bovine ABCG2 gene with a major effect on the QTL on chromosome 6 affecting milk yield and composition in Holstein cattle. Genome Res. 15:936-944.

Cole, J. B., P. M. VanRaden, J. R. O'Connell, C. P. Van Tassell, T. S. Sonstegard, R. D. Schnabel, J. F. Taylor, and G. R. Wiggans. 2009. Distribution and location of genetic effects for dairy traits. J. Dairy Sci. 92:2931-2946.

Cooper, T. A., G. R. Wiggans, and P. M. VanRaden. 2015. Short communication: Analysis of genomic predictor population for Holstein dairy cattle in the United States - Effects of sex and age. J. Dairy Sci. 98:2785-2788.

Daetwyler, H. D., A. Capitan, H. Pausch, P. Stothard, R. Van Binsbergen, R. F. Brondum, X. Liao, A. Djari, S. C. Rodriguez, C. Grohs, D. Esquerre, O. Bouchez, M.-N. Rossignol, C. Klopp, D. Rocha, S. Fritz, A. Eggen, P. J. Bowman, D. Coote, A. J. Chamberlain, C. Anderson, C. P. VanTassell, I. Hulsegge, M. E. Goddard, B. Guldbrandtsen, M. Lund, R. F. Veerkamp, D. A. Boichard, R. Fries, and B. J. Hayes. 2014. Whole-genome sequencing of 234 bulls facilitates mapping of monogenic and complex traits in cattle. Nat. Genet. 46:858-865. https://doi.org/10.1038/ng.3034.

Darvasi, A. 2005. Dissecting complex traits: The geneticists' 'Around the world in 80 days'. Trends Genet. 21:373-376.

De Donato, M., S. O. Peters, S. E. Mitchell, T. Hussain, and I. G. Imumorin. 2013. Genotyping-by-sequencing (GBS): A novel, efficient and cost-effective genotyping method for cattle using nextgeneration sequencing. PLoS One 8:e62137.

de Haas, Y., J. E. Pryce, M. P. L. Calus, E. Wall, D. P. Berry, P. Løvendahl, N. Krattenmacher, F. Miglior, K. Weigel, D. Spurlock, K. A. Macdonald, B. Hulsegge, and R. F. Veerkamp. 2015. Genomic prediction of dry matter intake in dairy cattle from an international data set consisting of research herds in Europe, North America, and Australasia. J. Dairy Sci. 98:6522-6534.

de Haas, Y., M. Pszczola, H. Soyeurt, E. Wall, and J. Lassen. 2017. Invited review: Phenotypes to genetically reduce greenhouse gas emissions in dairying. J. Dairy Sci. 100:855-870.

de Los Campos, G., J. M. Hickey, R. Pong-Wong, H. D. Daetwyler, and M. P. L. Calus. 2013. Whole-genome regression and prediction methods applied to plant and animal breeding. Genetics 193:327345.

Decker, J. E. 2015. Agricultural genomics: commercial applications bring increased basic research power. PLoS Genet. 11:e1005621.

Deol, M. S., H. Gruneberg, A. G. Searle, and G. M. Truslove. 1957 Genetical differentiation involving morphological characters in an inbred strain of mice. I. A British branch of the C57BL strain. J. Morphol. 100:345-376.

Druet, T., N. Ahariz, N. Cambisano, N. Tamma, C. Michaux, W. Coppieters, C. Charlier, and M. Georges. 2014. Selection in action: Dissecting the molecular underpinnings of the increasing muscle mass of Belgian Blue cattle. BMC Genomics 15:796-808.

Egger-Danner, C., J. B. Cole, J. E. Pryce, N. Gengler, B. Heringstad, A. Bradley, and K. F. Stock. 2015. Invited review: Overview of new traits and phenotyping strategies in dairy cattle with a focus on functional traits. Animal 9:191-207.

Falconer, D. S. 1964. Introduction to Quantitative Genetics. Oliver and Boyd Ltd., Edinburgh, UK.

Fisher, R. A. 1918. The correlation between relatives on the supposition of Mendelian inheritance. Proc. R. Soc. Edinb. 52:399-433.

García-Ruiz, A., J. B. Cole, P. M. VanRaden, G. R. Wiggans, F. J Ruiz-López, and C. P. Van Tassell. 2016. Changes in genetic selection differentials and generation intervals in US Holstein dairy cattle as a result of genomic selection. Proc. Natl. Acad. Sci. USA 113:E3995-E4004. 
Georges, M. 2007. Mapping, fine mapping, and molecular dissection of quantitative trait loci in domestic animals. Annu. Rev. Genomics Hum. Genet. 8:131-162.

Georges, M., D. Nielsen, M. Mackinnon, A. Mishra, R. Okimoto, A. T. Pasquino, L. S. Sargent, A. Sorensen, M. R. Steele, X. Zhao, J. E. Womack, and I. Hoeschele. 1995. Mapping quantitative trait loci controlling milk production in dairy cattle by exploiting progeny testing. Genetics 139:907-920.

Glick, G., A. Shirak, S. Uliel, Y. Zeron, E. Ezra, E. Seroussi, M. Ron, and J. I. Weller. 2012. Signatures of contemporary selection in the Israeli Holstein dairy cattle. Anim. Genet. 43(Suppl. 1):45-55.

Goddard, M. E., K. E. Kemper, I. M. MacLeod, A. J. Chamberlain, and B. J. Hayes. 2016. Genetics of complex traits: prediction of phenotype, identification of causal polymorphisms and genetic architecture. Proc. Biol. Sci. 283:20160569.

Grisart, B., W. Coppieters, F. Farnir, L. Karim, C. Ford, P. Berzi, N. Cambisano, M. Mni, S. Reid, P. Simon, R. Spelman, M. Georges, and R. Snell. 2002. Positional candidate cloning of a QTL in dairy cattle: Identification of a missense mutation in the bovine DGAT1 gene with major effect on milk yield and composition. Genome Res. 12:222-231.

Hayes, B., A. J. Chamberlain, H. Daetwyler, C. J. Vander Jagt, and M. E. Goddard. 2016. Improving genomic selection across breeds and across generations with functional annotation. J. Anim. Sci. 94(Suppl. 4):3-4. (Abstr.)

Hayes, B., R. Fries, M. S. Lund, D. A. Boichard, P. Stothard, R. F. Veerkamp, C. Van Tassell, C. Anderson, I. Hulsegge, B. Guldbrandtsen, D. Hinirichs, A. Bagnato, M. Georges, R. Spelman, J. Reecy, A. L. Archibald, M. Goddard, and B. Gredler. 2012. 1000 Bull Genomes Consortium Project. Abstract W139 in Proc. Plant and Animal Genome XX Conference, San Diego, CA.

Hayes, B., and M. E. Goddard. 2001. The distribution of the effects of genes affecting quantitative traits in livestock. Genet. Sel. Evol. $33: 209-229$.

Hill, W. G. 2008. Estimation, effectiveness and opportunities of longterm genetic improvement in animals and maize. Lohmann Inf. 43:3-20.

Hill, W. G. 2016. Is continued genetic improvement of livestock sustainable? Genetics 202:877-881.

Hu, Z.-L., C. A. Park, and J. M. Reecy. 2016. Developmental progress and current status of the Animal QTLdb. Nucleic Acids Res. 44:D827-D833.

Jenko, J., G. R. Wiggans, T. A. Cooper, S. A. E. Eaglen, W. G. de. L. Luff, M. Bichard, R. Pong-Wong, and J. A. Woolliams. 2017. Cow genotyping strategies for genomic selection in a small dairy cattle population. J. Dairy Sci. 100:439-452.

Kaupe, B., A. Winter, R. Fries, and G. Erhardt. 2004. DGAT1 polymorphism in Bos indicus and Bos taurus cattle breeds. J. Dairy Res. 71:182-187.

Kemper, K. E., B. J. Hayes, H. D. Daetwyler, and M. E. Goddard. 2015. How old are quantitative trait loci and how widely do they segregate? J. Anim. Breed. Genet. 132:121-134.

Kennedy, B. W. 1984. Selection limits: Have they been reached with the dairy cow? Can. J. Anim. Sci. 64:207-215.

Khatkar, M. S., P. C. Thomson, I. Tammen, and H. W. Raadsma. 2004. Quantitative trait loci mapping in dairy cattle: Review and meta-analysis. Genet. Sel. Evol. 36:163-190.

Koivula, M., I. Strandén, G. P. Aamand, and E. A. Mäntysaari. 2016. Effect of cow reference group on validation reliability of genomic evaluation. Animal 10:1061-1066.

Littlejohn, M. D., K. Tiplady, T. A. Fink, K. Lehnert, T. Lopdell, T. Johnson, C. Couldrey, M. Keehan, R. G. Sherlock, C. Harland, A. Scott, R. G. Snell, S. R. Davis, and R. J. Spelman. 2016. Sequencebased association analysis reveals an MGST1 eQTL with pleiotropic effects on bovine milk composition. Sci. Rep. 6:25376.

Liu, Z., H. Alkhoder, F. Reinhardt, and R. Reents. 2016. Accuracy and bias of genomic prediction for second-generation candidates. Proc. Interbull Mtg., Puerto Varas, Chile. Interbull, Uppsala, Sweden.

Loftus, R. T., O. Ertugrul, A. H. Harba, M. A. El-Barody, D. E. MacHugh, S. D. Park, and D. G. Bradley. 1999. A microsatellite survey of cattle from a center of origin: The Near East. Mol. Ecol. 8:2015-2022.

Lourenco, D. A. L., I. Misztal, S. Tsuruta, I. Aguilar, T. J. Lawlor, S. Forni, and J. I. Weller. 2014. Are evaluations on young genotyped animals benefiting from the past generations? J. Dairy Sci. 97:3930-3942.

Lund, M. S., I. van den Berg, P. Ma, R. F. Brøndum, and G. Su. 2016. How to improve genomic predictions in small dairy cattle populations. Animal 10:1042-1049.

Maher, B. 2008. Personal genomes: The case of the missing heritability. Nature 456:18-21.

Mäntysaari, E. A., and I. Strandén. 2016. Genomic data and breeding value estimation in dairy cattle: Theory, practice, problems. J. Anim. Breed. Genet. 133:165-166.

Manzanilla-Pech, C. I. V., Y. De Haas, B. J. Hayes, R. F. Veerkamp, M. Khansefid, K. A. Donoghue, P. F. Arthur, and J. E. Pryce. 2016. Genomewide association study of methane emissions in Angus beef cattle with validation in dairy cattle. J. Anim. Sci. 94:4151-4166.

McClure, M. C., D. Bickhart, D. Null, P. VanRaden, L. Xu, G. Wiggans, G. Liu, S. Schroeder, J. Glasscock, J. Armstrong, J. B. Cole, C. P. VanTassell, and T. S. Sonstegard. 2014. Bovine exome sequence analysis and targeted SNP genotyping of recessive fertility defects $\mathrm{BH} 1, \mathrm{HH} 2$, and $\mathrm{HH} 3$ reveal a putative causative mutation in SMC2 for HH3. PLoS One 9:e92769.

Miglior, F., B. L. Muir, and B. J. Van Doormaal. 2005. Selection indices in Holstein cattle of various countries. J. Dairy Sci. 88:12551263.

Misztal, I., and A. Legarra. 2017. Invited review: Efficient computation strategies in genomic selection. Animal 11:731-736.

Patry, C., and V. Ducrocq. 2011. Evidence of biases in genetic evaluations due to genomic preselection in dairy cattle. J. Dairy Sci. 94:1011-1020.

Pickering, N. K., M. G. G. Chagunda, G. Banos, R. Mrode, J. C. McEwan, and E. Wall. 2015. Genetic parameters for predicted methane production and laser methane detector measurements. J. Anim. Sci. 93:11-20.

Pryce, J. E., and H. D. Daetwyler. 2012. Designing dairy cattle breeding schemes under genomic selection: A review of international research. Anim. Prod. Sci. 52:107-114.

Pryce, J. E., B. J. Hayes, and M. E. Goddard. 2012. Genotyping dairy females can improve the reliability of genomic selection for young bulls and heifers and provide farmers with new management tools. Proc. 38th ICAR Session 28, Cork, Ireland. http://www.icar .org/Cork_2012/Manuscripts/Published/Pryce\%202.pdf.

Rauw, W. M., E. Kanis, E. N. Noordhuizen-Stassen, and F. J. Grommers. 1998. Undesirable side effects of selection for high production efficiency in farm animals: A review. Livest. Prod. Sci. 56:15-33.

Roehe, R., R. J. Dewhurst, C.-A. Duthie, J. A. Rooke, N. McKain, D. W. Ross, J. J. Hyslop, A. Waterhouse, T. C. Freeman, M. Watson, and R. J. Wallace. 2016. Bovine host genetic variation influences rumen microbial methane production with best selection criterion for low methane emitting and efficiently feed converting hosts based on metagenomic gene abundance. PLoS Genet. 12:e1005846.

Ron, M., Y. Blank, M. Band, E. Ezra, and J. I. Weller. 1996. Misidentification rate in the Israeli dairy cattle population and implications for genetic improvement. J. Dairy Sci. 79:676-681.

Ron, M., M. Cohen-Zinder, C. Peter, J. I. Weller, and G. Erhardt. 2006. ABCG2 polymorphism in Bos indicus and Bos taurus cattle breeds. J. Dairy Sci. 89:4921-4923.

Ron, M., D. W. Heyen, J. I. Weller, M. Band, E. Feldmesser, H. Pasternak, Y. Da, G. R. Wiggans, P. M. Vanraden, E. Ezra, and H. A. Lewin. 1998. Detection and analysis of a locus affecting milk concentration in the US and Israeli dairy cattle populations. Pages 422-425 in Proc. 6th World Congr. Genet. Appl. Livest. Prod., Armidale, Australia. WCGALP, Armidale, NSW, Australia.

Ron, M., and J. I. Weller. 2007. From QTL to QTN identification in livestock-Winning by points rather than knock-out: A review. Anim. Genet. 38:429-439.

Schaeffer, L. R. 1994. Multiple-country comparison of dairy sires. J. Dairy Sci. 77:2671-2678. 
Schöpke, K., and H. H. Swalve. 2016. Review: Opportunities and challenges for small populations of dairy cattle in the era of genomics. Animal 10:1050-1060.

Silva, M. V. B., D. J. A. dos Santos, S. A. Boison, A. T. H. Utsunomiya, A. S. Carmo, T. S. Sonstegard, J. B. Cole, and C. P. Van Tassell. 2014. The development of genomics applied to dairy breeding. Livest. Sci. 166:66-75.

Sonstegard, T. S., J. B. Cole, P. M. VanRaden, C. P. Van Tassell, D. J. Null, S. G. Schroeder, D. Bickhart, and M. C. McClure 2013. Identification of a nonsense mutation in CWC15 associated with decreased reproductive efficiency in Jersey cattle. PLoS One 8:e54872.

Stanton, T. L., L. R. Jones, R. W. Everett, and S. D. Kachman. 1992 Estimating milk, fat, and protein lactation curves with a test day model. J. Dairy Sci. 75:1691-1700.

Tan, W., D. F. Carlson, C. A. Lancto, J. R. Garbe, D. A. Webster, P. B. Hackett, and S. C. Fahrenkrug. 2013. Efficient nonmeiotic allele introgression in livestock using custom endonucleases. Proc. Natl. Acad. Sci. USA 110:16526-16531.

Taylor, J. F., L. K. Whitacre, J. L. Hoff, P. C. Tizioto, J. Kim, J. E. Decker, and R. D. Schnabel. 2016. Lessons for livestock genomics from genome and transcriptome sequencing in cattle and other mammals. Genet. Sel. Evol. 48:59.

Thomasen, J. R., A. Willam, C. Egger-Danner, and A. C. Sorensen. 2016. Reproductive technologies combine well with genomic selection in dairy breeding programs. J. Dairy Sci. 99:1331-1340.

Thomasen, J. R., A. Willam, B. Guldbrandtsen, M. S. Lund, and A. C. Sørensen. 2014. Genomic selection strategies in a small dairy cattle population evaluated for genetic gain and profit. J. Dairy Sci. 97:458-470

Uemoto, Y., T. Osawa, and J. Saburi. 2017. Effect of genotyped cows in the reference population on the genomic evaluation of Holstein cattle. Animal 11:382-393.

Van Tassell, C. P., T. P. L. Smith, L. K. Matukumalli, J. F. Taylor, R. D. Schnabel, C. Taylor Lawley, C. D. Haudenschild, S. S. Moore, W. C. Warren, and T. S. Sonstegard. 2008. SNP discovery and allele frequency estimation by deep sequencing of reduced representation libraries. Nat. Methods 5:247-252.

VanRaden, P. M., and P. G. Sullivan. 2010. International genomic evaluation methods for dairy cattle. Genet. Sel. Evol. 42:7.

VanRaden, P. M., M. E. Tooker, J. R. O'Connell, D. M. Bickhart, and J. B. Cole. 2017. Selecting sequence variants to improve genomic predictions for dairy cattle. Genet. Sel. Evol. In press.

VanRaden, P. M., C. P. Van Tassell, G. R. Wiggans, T. S. Sonstegard, R. D. Schnabel, J. F. Taylor, and F. S. Schenkel. 2009. Invited review: Reliability of genomic predictions for North American Holstein bulls. J. Dairy Sci. 92:16-24.

Weber, G. P. 1985. Rates of spontaneous mutation for quantitative traits in barley and soybeans. $\mathrm{PhD}$ dissertation. Iowa State University, Ames. http://lib.dr.iastate.edu/cgi/viewcontent.cgi?article $=13117 \&$ context $=$ rtd.

Weller, J. I. 2009. Quantitative Trait Loci Analysis in Animals. 2nd ed. CABI Publishing, London, UK.

Weller, J. I. 2016a. Genetic factors affecting fertility, growth, health and longevity in dairy cattle. Pages 209-242 in Achieving Sustain- able Production of Milk: Vol. 1. Milk Composition, Genetics and Breeding. N. van Belzen, ed. Burleigh Dodds Science Publishing Ltd., Cambridge, UK.

Weller, J. I. 2016b. Genomic Selection in Animals. John Wiley \& Sons Inc., Hoboken, NJ.

Weller, J. I., J. B. Cole, P. M. VanRaden, and G. R. Wiggans. 2014a. Application of the a posteriori granddaughter design to the Holstein genome. Animal 8:511-519.

Weller, J. I., G. Glick, E. Seroussi, and M. Ron. 2010. Paternity validation and estimation of genotyping error rate for the BovineSNP50 BeadChip. Anim. Genet. 41:551-553.

Weller, J. I., G. Glick, A. Shirak, E. Ezra, E. Seroussi, M. Shemesh, Y. Zeron, and M. Ron. 2014b. Predictive ability of selected subsets of single nucleotide polymorphisms (SNPs) in a moderately sized dairy cattle population. Animal 8:208-216.

Weller, J. I., M. Golik, E. Seroussi, E. Ezra, and M. Ron. 2003. Population-wide analysis of a QTL affecting milk-fat production in the Israeli Holstein population. J. Dairy Sci. 86:2219-2227.

Weller, J. I., J. Z. Song, D. W. Heyen, H. A. Lewin, and M. Ron. 1998. A new approach to the problem of multiple comparisons in the genetic dissection of complex traits. Genetics 150:1699-1706.

Weller, J. I., W. M. Stoop, H. Eding, C. Schrooten, and E. Ezra. 2015 Genomic evaluation of a relatively small dairy cattle population by combination with a larger population. J. Dairy Sci. 98:4945-4955.

Westell, R. A., R. L. Quaas, and L. D. Van Vleck. 1988. Genetic groups in an animal model. J. Dairy Sci. 71:1310-1318.

Wiggans, G. R., J. B. Cole, S. M. Hubbard, and T. S. Sonstegard 2017. Genomic selection in dairy cattle: The USDA experience. Annu. Rev. Anim. Biosci. 5:309-327.

Wiggans, G. R., T. A. Cooper, P. M. VanRaden, C. P. Van Tassell, D. M. Bickhart, and T. S. Sonstegard. 2016. Increasing the number of single nucleotide polymorphisms used in genomic evaluation of dairy cattle. J. Dairy Sci. 99:4504-4511.

Wiggans, G. R., P. M. VanRaden, and T. A. Cooper. 2012. Technical note: Adjustment of all cow evaluations for yield traits to be comparable with bull evaluations. J. Dairy Sci. 95:3444-3447.

Wiggans, G. R., and J. I. Weller. 2015. Revisiting the "a posteriori" granddaughter design. Interbull Bull. 49:36-42.

Winter, A., W. Kramer, F. A. O. Werner, S. Kollers, S. Kata, G. Durstewitz, J. Buitkamp, J. E. Womack, G. Thaller, and R. Fries. 2002. Association of a lysine-232/alanine polymorphism in a bovine gene encoding acyl-CoA:diacylglycerol acyltransferase (DGAT1) with variation at a quantitative trait locus for milk fat content. Proc. Natl. Acad. Sci. USA 99:9300-9305.

Yang, J., B. Benyamin, B. P. Mc, S. Evoy, A. K. Gordon, D. R. Henders, P. A. Nyholt, A. C. Madden, N. G. Heath, G. W. Martin, M. E. Montgomery, M. E. Goddard, and P. M. Visscher. 2010. Common SNPs explain a large proportion of heritability for human height. Nat. Genet. 42:565-569.

Yin, T., T. Pinent, K. Brügemann, H. Simianer, and S. König. 2015 Simulation, prediction, and genetic analyses of daily methane emissions in dairy cattle. J. Dairy Sci. 98:5748-5762. 